\title{
Association between Septoria tritici Blotch, Plant Height, and Heading Date in Wheat
}

\author{
María Rosa Simón,* Analía E. Perelló, Cristina A. Cordo, Silvina Larrán, \\ Peter E. L. van der Putten, and Paul C. Struik
}

\begin{abstract}
The relationship between resistance to Septoria tritici blotch with plant height and heading date has been in most cases attributed to genetic associations. More efficient selection for higher levels of quantitative resistance may result if the nature of the association between susceptibility with earliness and shortness can be determined. Genetic resistance to Septoria tritici blotch and its relationships with plant height and heading date were recorded in 50 Argentinean wheat (Triticum cestivum L.) cultivars in three environments (two in the field and one in the greenhouse) with one virulent isolate of Mycosphaerella graminicola (Fuckel) Schroeter, in Cohn (anamorph Septoria tritici Roh. ex Desm.). Furthermore, a set of 16 cultivars was tested with seven isolates of $M$. graminicola in the greenhouse at the adult stage. Cultivars varied greatly in resistance to the disease and plant matcrial was identified with moderate to high levels of resistance to several isolates. The field and greenlouse experiments demonstrated no evidence of genetic associations between plant height, heading date, and resistance, indicating that selection of early and short lines with high levels of quantitative resistance is possible. The relationships between those traits were mainly caused by environmental and epidemiological factors, which indicates that management of cultivars should be optimized to ininimize these associations.
\end{abstract}

$M$ YCOSPHAERELLA GRAMINICOLA (Fuckel) Schroeter, in Cohn is an important disease in many wheatproducing areas of the world and causes significant yield losses (King et al., 1983; Eyal et al., 1985, 1987; Van Ginkel and Rajaram, 1993). It is a major problem in regions characterized by a temperate, wet environment during the growing season (Eyal et al., 1987). Breeding for resistance is the most economical approach to control the disease. Resistance controlled by one major gene was iclentified in some plant materials (Rillo and Caldwell, 1966; Rosielle and Brown, 1979; Wilson, 1979; Lee and Gough, 1984). Resistance based on several genes also was identified (Rosielle and Brown, 1979). Jlibene and El Bouami (1995) indicated that several components of the partial resistance to Septoria tritici blotch also may be controlled by only one or a few genes that could be combined into the same genetic background by crossing. Several quantitative studies have indicated

M.R. Simón, Curcalicultura, Dep. Tecnología Agropecuaria y Forcstal; A.E. Perello, CIDEFI, Dep. Ciencias Biolugicas-CONICET; C.A. Cordo, CIDEFI, Dep. Ciencias Biológicas-ClC; S. Larrán, CIDEFI, Dep. Ciencias Biológicas, Facultad de Ciencias Agrarias y Forestales, Univ. Nacional de La Plata, 60 y 119, C.C 31, 19(1) La Plata, Argentina; and P.E.L. van der Putten and P.C. Struik, Dep. of Plant Sciences, Wageningen Univ., Haarweg 333, 67) 9 RZ, Wageningen, the Netherlands. This work was lunded by ANPCYT, Argentina (PICT (08-()6.356 and 8-14489) and SECYT, UNLP (A 144) Received 12 May $20(1) 4$. *Corresponding author (misimon(@)agro.unlp.edu.ar).

Published in Agron. J. 97:1072-1081 (20)(05).

Plant Discasc

doi:1().21.34/agronj2()()3.(1)126

(C) American Sucicty of Agronomy

677 S. Scgoc Rd., Madison, WI 5.3711 USA the presence of general combining ability, although specific combining effects are also present (Van Ginkel and Scharen, 1987; Danon and Eyal, 1990; Jlibene et al., 1994; Simón and Cordo, 1997, 1998).

In Argentina, breeders classify most commercially grown cultivars in the range of moderately resistant to susceptible, suggesting the presence of quantitative, nonspecific resistance in some of them, although isolatespecific resistance also could be present. However, an accurate characterization is needed. Specific interaction between cultivars and isolates of $M$. graminicola has been reported (Van Ginkel and Scharen, 1987; Danon and Eyal, 1990; Jlibene et al., 1994; Kema et al., 1996a, 1996b, 1997; Simón and Cordo, 1997, 1998; Brown et al., 2001).

One of the most complicating factors in determining resistance to Septoria tritici blotch is the interaction between resistance, plant height, and heading date. Several scientists reported increased disease severity in earlier heading and shorter cultivars (Eyal et al., 1987; Van Beuningen and Kohli, 1990; Camacho Casas et al., 1995). Baltazar et al. (1990) suggested a genetic association between shortness and susceptibility, while Eyal (1981) and Rosielle and Boyd (1985) assumed a genetic association between earliness and susceptibility. Arama et al. (1999) reported no influence of heading date when cultivars were evaluated at the same development stage under similar weather conditions. From several investigations it is not clear if these associations are due to genetic or epidemiological factors.

The aims of this work were to determine (i) the resistance in a broad range of wheat cultivars grown in Argentina at the seedling and adult stages to one virulent isolate of Mycosphaerella graminicola; (ii) the relationship between resistance to $M$. graminicola, plant height and heading date in those cultivars; and (iii) the resistance in a set of wheat cultivars at the adult stage using several Argentinean isolates.

\section{MATERIALS AND METHODS}

\section{Field Experiments}

Filty cultivars of wheat were tested in field experiments in 1998 and 20(0) at the Estacion Experimental Facultad de Ciencias Agrarias y Forestales, Los Hornos, Argentina. The cultivars differed in plant height, heading date, and resistance to Septoria tritici blotch, and represented the range in these characteristics for cultivars grown in Argentina in 1998. 'Klein Toledo', an old cultivar, also was included because it is moderately resistant to Septoria tritici blotch (Gieco et al., 20(1)4).

The field experiments were isolated 30() $\mathrm{m}$ from other wheat experiments in both years. For each experiment, cultivars were

Abbreviations: AUDPC, arca under discase progress curve; GS, growth stage; PDA, potato dextruse agar. 
arranged in a randomized block design with three replicates separated by $3 \mathrm{~m}$ of oat (Avena sativa L.) to avoid interplot interference. Plots, also separated by two rows of oat, consisted of three $3 \mathrm{~m}$ long rows. The experiments were sown on 24 June 1998 (emergence on 5 July 1998) and 5 July 20()() (emergence on 23 July 2()()$(1)$. At sowing, both experiments were fertilized with 5() $\mathrm{kg} \mathrm{ha}^{-1}$ of $\mathrm{P}$ as ammonium diphosphate and 1()() $\mathrm{kg}$ $\mathrm{ha}^{-1} \mathrm{~N}$ as urea.

The Argentinean isolate of $M$. graminicola named IPO 99()13 by the former IPO-DLO, now part of the Plant Research Inteinational, Wageningen, the Netherlands, was grown on Petri-dishes of potato dextrose agar (PDA) 2\% (Plant Pathologist's Pocketbook, 1974) and transferred to malt extract agar (Plant Pathologist's Pocketbook, 1974) at $19^{\circ} \mathrm{C}$ with $12 \mathrm{~h}$ alternating light and dark cycles. The isolate was selected according to a previous greenhouse test with 5 cultivars and !() isolates, where isolate $99(13$ showed contrasting results between cultivars (unpublished data). Inoculum was prepared by aseptically scraping sporulating colonies with a scalpel and suspending conidia in deionized water. The conidial suspension was adjusted for both years and both growth stages to $5 \times 10^{6}$ spores $\mathrm{mL}^{-1}$. Tween 2() (Polyoxyethylene sorbitan monolaurate, SigmaAldrich) at (1.5 $\mathrm{mL} \mathrm{L} \mathrm{L}^{-1}$ was added as a surfactant. Plots were inoculated at two-leaf seedling stage (GS i2, Zadoks et al., 1974 ) and at tillering stage (GS 22) in both years with a hand pump. For each plot, $7(0) \mathrm{mL}$ of inoculum were sprayed at each inoculation stage. After inoculations, plants were kept moist by spraying with water with a sprayer for applying pesticides, several times a day for $3 \mathrm{~d}$. Plants ivere sprayed with Plantvax (oxycarboxin; 5,6 dihydro-2-methyl- $N$-phenyl-1, 4 oxathiin-3-carboxamide 4,4 dioxide; Dhanuka Group, New Dehli, India) when the first symptoms of leaf rust (caused by Puccinia triticina Eriks) appeared.

Percentage of necrosis and pycnidial coverage were visually estimated in seedlings on the second leal at $26 \mathrm{~d}$ after the tirst inoculation at the same time for all cultivars. Evaluations started when Septoria tritici blotch was well expressed in the known susceptible cv. Buck Ombú, used as a control. Evaluations also were done at booting (GS 49), milk development (GS 7()), and early dough (GS 83) stages. The three upper leaves of each plant (flag leaf, flag leaf-1, flag leaf-2) were evaluated at the latter three stages (adult stages). Twenty plants were rated in the central row of each plot at each growth stage. Plant height, measured from the soil to the flag leaf and heading date, the time from plant emergence to when $50 \%$ of the spikes emerged from the hoot, also were recorded in each plot. Height to flag leaf was measured instead of tip of ear because Septoria tritici blotch usually progresses up to the flag leaf in the Argentina growing wheat area and it was not evaluated in the ears. An area under disease progress curve (AUDPC) for each cultivar and each treatment was calculated to summarize the progress of the disease, according to the formula of Shaner and Finney (1977). Cultivars were considered resistant when pycnidial coverage was up to $20 \%$, moderately resistant between 21 and $40 \%$, moderately susceptible between 41 and $6(1) \%$, and susceptible with more than $6(1) \%$.

Weather conditions (precipitation; minimum, maximum, and mean relative humidity; minimum, maximum, and mean daily temperature; and mean daily radiation) were recorded at a meteorological station situated $1(1)(1) \mathrm{m}$ from the experiments. In 1998, measurements of daily global radiation were not started until 3 September due to failure of the equipment. The first inoculation and the final evaluation were on $17 \mathrm{July}$ and 22 Nov. 1998 and on 10 Aug. and 5 Dec. 2(1)(), respectively. For these periods, mean daily temperatures were 13.9 and $14.4^{\circ} \mathrm{C}$, mean relative humidity 85 and $83 \%$, mean global radiation 4537 and $410(1) \mathrm{W} \mathrm{m}^{-2} \mathrm{~d}^{-1}$, and total precipitation 198 and
$388 \mathrm{~mm}$ for 1998 and 2()()() , respectively. Long-term averages mean temperatures for the period July-November and August-December are 14.3 and $16.8^{\circ} \mathrm{C}$, respectively, and longterm precipitation for the same periods are 393 and $4(19 \mathrm{~mm}$.

Data were transformed using arcsine square root and analyzed by a combined ANOVA for both years for a randomized block Jesign. They were transformed to adjust them to a normal distribution and stabilize the residual variance. Cultivars and years were considered as fixed effects. Because of some significant cultivar $\times$ experiment interactions, a separate analysis for each year was also performed. Multiple linear and nonlinear regression analyses were performed with pycnidial coverage as the dependent variable and heading date and plant height as the independent variables. Models were generated with SAS (SAS Inst., 1989). Best models were those with the highest $R^{2}$, fewest number of parameters, and lowest Mallows C.p statistics. Data are presented in the tables as the backtransformed values.

\section{Greenhouse Experiments}

\section{Experiment 1}

The 50 wheat cultivars used in the field experiments were sown in a randomized block design with three replications in a growth chamber under controlled conditions at the Department of Plant Sciences, Wageningen University, the Netherlands, in 1999. Eight seeds per cultivar per replication were placed in 1 - $L$ plastic pots containing a sandy soil and fertilized with $1(1) \mathrm{kg} \mathrm{N}^{-1}$ as urea and 5() $\mathrm{kg} \mathrm{P}$ as ammonium diphosphate. Temperature was kept at 7 to $9^{\circ} \mathrm{C}$, relative humidity at 7() to $75 \%$, and photoperiod at $10 \mathrm{~h}$. At tillering (GS 22), six to eight plants were transplanted to 1()$-\mathrm{L}$ plastic pots with the same soil and fertilizer application and transferred to a greenhouse at 15 to $18^{\circ} \mathrm{C}, 7(1) \%$ relative humidity, and 13 to $14 \mathrm{~h}$ photoperiod, after an adaptation period of $3 \mathrm{~d}$ at $12^{\circ} \mathrm{C}$ to simulate similar conditions to those of the growing wheat area in Argentina. Pots were watered each 2 or $3 d$ with tap water as required to keep the soil wet.

At heading (GS 59) plants were inoculated with the same isolate (IPO $y() 13$ ) as the one used in field experiments. Inoculation was done with a liand pump saturating the upper two leaves. Plants were inoculated in three groups according to their heading dates (from $8(1) .5$ to $88.5,89$ to 94.5 , and 95 to $1(1) \mathrm{d}$ to heading) and all were maintained in the same environmental conditions after inoculation. Plants were covered with a transparent plastic tent to maintain humidity at very high levels (>95\%) for $72 \mathrm{~h}$. After that, temperature was maintained between 17 and $22^{\circ} \mathrm{C}$ and relative humidity was kept between 75 and $85 \%$. Two humidifiers ivere placed in the greenhouse to maintain those humidity levels. Although conditions were maintained as stable as possible, the control cultivars Klein Volcán (classified by breeders as moderately resistant) and Buck Ombú (susceptible) were planted at three different dates and inoculated in the three groups to detect if any envirommental variation was influencing the results. Percentage of necrosis and pycnidial coverage were evaluated visually on the two upper leaves (flag leaf and flag leaf-l) of 1 () to 15 main tillers per pot $24 \mathrm{~d}$ after inoculation (GS 83). Data were transformed using arcsine square root to adjust them to a normal distribution and to stabilize the residual variance and analyzed by ANOVA for randomized block designs. A preliminary ANOVA including the controls inoculated in the three groups differing in heading date was done. Controls did not show differences between the three inoculation groups. For that reason, values were not adjusted, and the final ANOVA was done without the controls. Multiple 
Table 1. Mean squares for the combined analysis of variance of pycnidial coverage percentage caused by Mycosphaerella graminicola at four growth stages, for the area under clisease progress curve (AUDPC), plant height, and days to heading in 50 Argentinean wheat cullivars in two field experiments.

\begin{tabular}{|c|c|c|c|c|c|c|c|c|}
\hline $\begin{array}{l}\text { Source of } \\
\text { variation" }\end{array}$ & If & Seedlings & GS49: & GS7II & GS83 & AUDPC & Plant height & Days to headling \\
\hline Cultivars & 49 & $378.4(P<(1 .(\mathrm{H}) 1) \dagger$ & $31.1(P<11 .(11) 1)$ & $262.9(P<11.1111)$ & $519.1)(P<11 .(K) 1)$ & $313372(P<11.11(11)$ & $2(15.2(P<1) .11(1) 1)$ & $197.2(P<(1 .(Y) 1)$ \\
\hline Experiments & 1 & (546.3 $(P<0.11(11)$ & $11168(P<11 .(1) 1)$ & $2 A 11113(P<11.1111)$ & $25(622(P<11 .(H) 1)$ & $25(15331 \mathrm{MI}(P)<1 .(1)(1)$ & $2775(P<() .(K) 1)$ & $1236(P<1) .(1) 1)$ \\
\hline $\begin{array}{l}\text { Cultivars } \times \\
\text { Experiments }\end{array}$ & 49 & $126.2(P<11 .(1) 1)$ & $24.16(P<11 .(1) 1)$ & $191.2(P<11 .(101)$ & $216.1(P<11.1(1) 1)$ & $168245(P<1) .(1111)$ & $25.6(P<1) .118)$ & $16.1)(P<1) .(101)$ \\
\hline Error & 198 & 58.4 & 8.19 & 23.8 & 57.4 & 19173 & 19.11 & 1.79 \\
\hline
\end{tabular}

$+\boldsymbol{P}>\boldsymbol{F}$.

†े GS 49, GS 711, GS 83 (growth stages; Zadoks et al., 1974).

linear and nonlinear regression analyses with pycnidial coverage as the dependent variable and heading date and plant height as the independent variables also were conducted. Data are presented in the tables as the backtransformed values.

\section{Experiment 2}

Sixteen cultivars - chosen according to differences in resistance to Septoria tritici blotch, heading date, and plant height from the field experiments - were sown in a factorial randomized block design with two replications in a growth chamber under controlled conditions at the Department of Plant Science, Wageningen University, the Netherlands, in 1999. Factors were the 16 cultivars and 7 isolates of $M$. graminicola. Three isolates (IPO 92064, 92(065, and 93014) were selected because they had shown differences in virulence with five genotypes in a previous screening (Simón et al., 20(0)1) and four others (IPO 99()13, 99()14, 99()15, and 99016) because they were new isolates to be tested. Eight seeds per treatment per replication were placed in $1-L$ pots with the same soil and fertilizer regimen as in the previous greenhouse experiment. Conditions in the growth chamber and after transplanting to the greenhouse were similar to Experiment 1. Pots were watered each 2 or $3 \mathrm{~d}$.

At heading (GS 59), plants were inoculated with the seven Argentinean isolates. Isolates were grown on Petri dishes of Campbell V8 juice agar for $3 \mathrm{~d}$ and transferred to yeast-glucose liquid medium (glucose, $10 \mathrm{~g} \mathrm{~L}^{-1}$ and yeast extract, $30 \mathrm{~g} \mathrm{~L}^{-1}$ ). Flasks were shaken for $5 \mathrm{~d}$ at $18^{\circ} \mathrm{C}$. Spores were resuspended in distilled water and the concentration adjusted to $1 \times 11^{7}$ spores $\mathrm{mL}^{-1}$. Tiveen $20\left(0.5 \mathrm{~mL} \mathrm{~L}^{-1}\right)$ was added as a surfactant. Plants were inoculated in three groups according to their heading date (from 84 to $88.5,89$ to 94.5 , and 95 to 100$) \mathrm{d}$ to heading). The same cultivars as in the Experiment I were used as controls at each inoculation date and inoculated with each of the seven isolates. Plants were covered with a transparent plastic tent to maintain humidity at very high levels (>95\%) for $72 \mathrm{~h}$. After that, the temperature in the greenhouse was between 17 and $22^{\circ} \mathrm{C}$ and the relative humidity was kept between 75 and $85 \%$ using humidifiers.

Percentage of necrosis and pycnidial coverage were evaluated $24 \mathrm{~d}$ after inoculation (GS 83) on the two upper leaves of 10 to 15 main tillers per pot. Data were transformed using arcsine square root to adjust them to a normal distribution and stabilize the residual variance and analyzed by ANOVA for factorial experiments. Data are presented in the tables as the backtransformed values. Controls did not show significant differences between the three inoculation groups, and for that reason values were not adjusted.

\section{RESULTS}

\section{Field Experiments}

Because of greater precipitation, environmental conditions were more conducive to the development of the disease in 2000. The combined analysis of variance for hoth years showed that pycnidial coverage was significantly different $(P<0.001)$ for cultivars, experiments, and the cultivar $\times$ experiment interaction at all four growth stages. There were also significant differences between cultivars and experiments in AUDPC, days to heading and plant height. The cultivar $\times$ experiment interaction was significant for the AUDPC $(P<0.001)$ and days to heading $(P<0.001)$ but not for plant height $(P=0.08)$ (Table 1$)$. Because of the significant experiment effects and cultivar $\times$ experiment interaction, a separate analysis was performed for each experiment (1998 and 2000). Cultivars were significant for all traits in both years $(P<0.001)$ (Table 2$)$.

Percentage pycniclial coverage was higher in 2000 than in 1998 in the seedling stage (Table 1 and 3). Mean percentage of pycnidial coverage across cultivars with isolate IPO 99013 ranged from 2.13 to $77.5 \%$ in 1998 and from 19.5 to $78.8 \%$ in 2000 (i.e., from resistant to susceptible) (Table 3). In spite of some variation in cultivar behavior between experiments, 'Klein Estrella' and Klein Volcán showed relatively high levels of resistance in both years. Some other cultivars (Klein Dragón, Buck Chambergo, ProINTA Puntal, Klein Don Enrique, Buck

Table 2. Mean squares for the separated analysis of variance for 2 yr of pycnidial coverage percentage caused by $M y c o s p h a e r t l a$ graminicola at four growth stages, for the area under disease progress curve (AUDPC), plant height, and days to heading in 50 Argentinean wheat cultivars in two field experiments.

\begin{tabular}{|c|c|c|c|c|c|c|c|c|c|c|c|c|c|c|c|}
\hline \multirow[b]{3}{*}{ Source of variation } & \multirow[b]{3}{*}{ df } & \multicolumn{8}{|c|}{ Pycnidial coverage } & & & & & & \\
\hline & & \multicolumn{2}{|c|}{ Seedllings } & \multicolumn{2}{|c|}{ 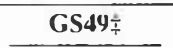 } & \multicolumn{2}{|c|}{ GS711 } & \multicolumn{2}{|c|}{ GS83 } & \multicolumn{2}{|c|}{ AUDPC } & \multicolumn{2}{|c|}{ Plant height } & \multicolumn{2}{|c|}{ Days III hearling } \\
\hline & & 1998 & 2011110 & 1998 & 201010 & 1998 & 201010 & 1998 & $201(10)$ & 1998 & $201111)$ & 1998 & 2111110 & 1998 & 2011111 \\
\hline & & & & & & $\%$ & & & - & & & & & & \\
\hline Cultivarstr & 49 & 3311.4 & 223.4 & 13.12 & 42.15 & 44.31 & $4(18.9$ & 285.1 & 4511.1 & 63157 & 418459 & 126.6 & 1114.1 & 117.6 & 95.6 \\
\hline Error & 98 & $6(1) .11$ & 35.11 & 4.14 & 11.811 & 111.118 & 35.63 & 57.13 & 58.611 & 11321 & 271194 & 14.5 & 17.5 & 1.63 & 1.81 \\
\hline
\end{tabular}

Cultivars were significant at $P<11.001$ for all traits.

†े GS 41, GS 7II, GS 8.3 (growth stages; Zadoks et al., 1974). 
Fogón, Buck Panadero) showed moderate level of resistance.

In all adult stages during which observations were made, average percentage of pycnidial coverage across cultivars was higher in 2000 than in 1998 (Table 4). The same difference between experiments was found for the AUDPC. However, some cultivars showed similar values for both experiments causing the cultivar $\times$ experiment interaction. For the AUDPC those cultivars were: Cooperación Calquín, Cooperación Millán, Granero INTA, Klein Don Enrique, Klein Dragón, Klein Estrella, Klein Pegaso, Klein Volcán, and ProINTA Federal. At GS 49 and GS 70, disease levels were very low in 1998. The means of the three upper leaves fluctuated between 0.0 and 2.58 in 1998 and 0.04 and 8.60 in 2000, 0.31 and 13.2 in 1998 and 0.76 and 53.5 in 2000, and 10.5 and 78.0 in 1998 and 22.3 and 94.0 in 2000 at GS 49, GS 70, and GS 83, respectively. The AUDPC values fluctuated between 123 and 718 and 274 and 1583 in 1998 and 2000, respectively.

Septoria tritici blotch always reached the flag leaf at GS 83, although Klein Dragón, Klein Estrella, Klein Volcán, Cooperación Millán, and Granero INTA showed very low values on that leaf in both years (data not shown). Those cultivars also showed moderate levels of resistance in both field experiments. The old cultivar Klein Toledo along with ProINTA Quintal also were moderately resistant to Septoria tritici blotch (Table 4).

Pycnidial coverage percentages at the seedling and adult stages were correlated. The correlation was higher in $2000(r=0.68, P<0.001, n=50)$ than in $1998(r=$ $0.26, P=0.06, n=50)$. Klein Estrella, Klein Volcán, and Klein Dragón, which showed the best levels of resistance at the seedling stage, also showed low pycnidial coverage in the adult stage with isolate IPO 99013. Most susceptible cultivars in the seedling stage were also susceptible in the adult stage. Although statistically significant, the correlation coefficients were low because cultivars such as Cooperación Millán and Granero INTA showed moderate levels of resistance in the adult stage but were more susceptible in the seedling stage. Some other cultivars such as Buck Chambergo with moderate levels of resistance in seedlings were more susceptible in the adult stage, especially in 2000. Correlation coefficients between percentage necrosis and pycnidial coverage were $0.75,0.70,0.81$, and 0.79 in 1998 and $0.78,0.93$, 0.86 , and 0.81 for 2000 at seedling stage, GS 49, GS 70, and GS 83, respectively (significant at $P<0.001$ ) (data not shown).

For the average of both experiments, differences in extremes among cultivars were $20 \mathrm{~d}$ in heading date (from 89 to 112 d in 1998 and from 89 to 106 in 2000) and $30 \mathrm{~cm}$ in plant height (from 61 to 92 in 1998 and from 54 to 82 in 2000) (Table 5). Cultivars with high or moderate levels of resistance in seedling and adult stage to isolate IPO 99013 were found among those with early heading date and short stature. For example, Cooperación Millán and Granero INTA showed moderate levels of resistance in the adult stage and are early heading cultivars with short to intermediate plant stature. Klein Toledo was the earliest cultivar in the field experiments
Table 3. Pycnidial coverage percentage (backtransformed values) caused by Mycosphaerella graminicola in seedlings of 50) Argentinean wheat cultivars in two field experiments.

\begin{tabular}{|c|c|c|c|}
\hline \multirow[b]{2}{*}{ Cultivarsi } & \multicolumn{3}{|c|}{ Pycnidial coverage } \\
\hline & 1998 & 20010 & Avg. \\
\hline & & $-\%-$ & - \\
\hline Klein Estrella & 2.13 & 25.11 & 13.6 \\
\hline Klein Volcán & 2.47 & 28.2 & 15.3 \\
\hline Klein Dragón & 36.11 & 19.5 & 27.7 \\
\hline Buck Chambergo() & 25.3 & 39.2 & 32.2 \\
\hline ProINTA Puntal & 18.2 & 47.7 & 32.9 \\
\hline Klein Don Enriyue & 49.1 & 21.8 & 35.4 \\
\hline Buck Fogion & 29.11 & 42.11 & 35.5 \\
\hline Buck Panadero & 30.4 & 41.7 & 36.11 \\
\hline Buck Poncho & 36.5 & 45.8 & 41.1 \\
\hline Thomas Chapelon & 37.8 & 44.7 & 41.2 \\
\hline Klein Cobre & 37.5 & 47.4 & 42.4 \\
\hline ProINTA Pigïe & 35.5 & 511.6 & $43.1)$ \\
\hline Klein Tuledu & 33.1 & 55.11 & 4.11 \\
\hline Cooperación Malambo & 41.3 & 47.2 & 4.2 \\
\hline ProINTA Federal & 54.3 & 34.7 & 4.5 \\
\hline ProlNTA Imperial & 31.7 & 58.3 & 45.11 \\
\hline Cooperación Calyuín & 4.9 & 46.6 & 45.7 \\
\hline Buck Charrúa & 39.6 & 54.4 & 47.11 \\
\hline ProINTA Granar & 54.6 & 39.5 & 47.11 \\
\hline Klein Pegasu & 53.7 & 41.1 & 47.4 \\
\hline Buck Arrayán & 52.5 & 48.3 & 50.4 \\
\hline Buck Candil & $5(1.9$ & 511.1 & 511.5 \\
\hline Thomas Aconcagua & 50.6 & 511.6 & 50.6 \\
\hline Buck Pronto & 51.5 & $5(1.1$ & $5(1) .8$ \\
\hline Granero INTA & 62.11 & 411.3 & 51.1 \\
\hline Bonaerense Pericón & 511.7 & 51.8 & 51.2 \\
\hline Buck Ombú & 47.8 & $5 \overline{5.2}$ & 51.5 \\
\hline ProINTA Super & 53.8 & 49.3 & 51.6 \\
\hline ProlNTA Cinco Cerros & 41.0 & 63.1 & 52.11 \\
\hline ProlNTA Quintal & 43.9 & 61.2 & 52.6 \\
\hline Klein Brujo & 52.8 & 54.1 & 53.4 \\
\hline Cooperación Millán & 64.9 & 43.3 & 54.1 \\
\hline Cooperación Maipún & 47.7 & 62.2 & $54 . \%$ \\
\hline ProINTA Guazí & 55.9 & 55.11 & 55.4 \\
\hline Cooperación Nahuel & 56.6 & 54.9 & 55.7 \\
\hline Klein Cacicue & 52.5 & 61.7 & 57.1 \\
\hline Klein Granador & $56.1)$ & 59.11 & 57.5 \\
\hline ProlNTA Elite & 59.7 & 56.2 & 57.9) \\
\hline Klein Centauro & 55.4 & 61.4 & 58.4 \\
\hline ProlNTA Bonaerense Caucpuén & $5 \% .8$ & 57.11 & 58.4 \\
\hline Klein Oriín & 53.7 & 63.3 & 58.5 \\
\hline Buck Catriel & 56.8 & 62.7 & $5 \% .7$ \\
\hline ProINTA Real & 53.7 & $7(1.8$ & 62.2 \\
\hline ProlNTA Bonderense Redomón & 61.3 & 63.3 & 62.3 \\
\hline Buck Guarani & 56.5 & 711.1 & 63.3 \\
\hline Buck Arriero & 65.8 & 64.5 & 65.1 \\
\hline Thumas Nevado & 53.1 & 78.8 & 65)$. \\
\hline ProINTA Oasis & 66.5 & 66.3 & 66.4 \\
\hline Thomas Tupungattı & 71.9) & 61.8 & 66.8 \\
\hline Bunaerense Pasuco & 77.5 & 69.11 & 73.2 \\
\hline Avg. & 47.6 & 51.7 & 41).6 \\
\hline LSD(1).115) & 12.5 & 9.6 & \\
\hline
\end{tabular}

$\uparrow$ Cultivars are placed in order according to the average of pycnidial coverage for hoth years.

$\doteqdot$ LSD test $(P<0.115)$ for comparison of pycnidial coverage percentage hetween cultivars within 2 yr.

and has been considered for many years to be one of the most resistant cultivars in Argentina. This cultivar showed moderate levels of resistance in the adult stages in these experiments.

Multiple linear regression analysis between pycniclial coverage as the dependent variable and plant height and heading date as the independent variables yielded significant $R^{2}$ values in 1998 for the growth stages GS 49, GS 70, and GS 83 and for the AUIDPC ( $P=0.06)$, but not for the seedling stage. Regression coefficients were negative and significant for days to heading at GS 49 and GS 70 and for plant height at GS 83 and for the 
Tal)le 4. Pycnidial coverage percentage (backtransformed values) caused by Mycosphaerella graminicola in 50 Argentinean wheat cultivars at three adult growth stages and area under disease progress curve (AUDPC) in two field experiments.

\begin{tabular}{|c|c|c|c|c|c|c|c|c|c|c|c|c|}
\hline \multirow[b]{2}{*}{ Cultivarst } & \multicolumn{3}{|c|}{ GS49 } & \multicolumn{3}{|c|}{ GS711 } & \multicolumn{3}{|c|}{ GS83 } & \multicolumn{3}{|c|}{ AUDPC } \\
\hline & 1998 & $2(1) 11)$ & $\begin{array}{c}\text { Mean } \\
1998-211)(1)\end{array}$ & 1998 & 211111 & $\begin{array}{c}\text { Mean } \\
1998-211111\end{array}$ & 1998 & $2(1)(1)$ & $\begin{array}{c}\text { Mean } \\
\text { 1998-2(1)(I) }\end{array}$ & 1998 & $211) 11$ & $\begin{array}{c}\text { Mean } \\
1998-211111\end{array}$ \\
\hline Klein Dragín & 10.16 & 11.114 & (1.11) & 11.99 & 3.82 & 2.411 & 16.8 & 27.7 & 22.2 & 151 & 283 & 217 \\
\hline Klein Estrella & 11.12 & $(1.51)$ & (1..31 & 0.31 & 4.11 & 2.21 & 22.9 & 25.6 & 24.2 & 189 & 274 & 231 \\
\hline Klein Volcain & 11.52 & 11.117 & 11.29 & 11.39 & 10.76 & 10.57 & 23.1 & 29.11 & $26.1)$ & 195 & 245 & 2211 \\
\hline Conperación Millain & 11.37 & 11.119 & 11.23 & 1.53 & 11.6 & 6.116 & 29.9 & 22.3 & 26.1 & 267 & 349 & 3118 \\
\hline Granero INTA & 1.511 & 1.52 & 1.51 & 3.14 & 5.119 & 4.11 & 17.5 & 37.11 & 27.2 & 2112 & 389 & 296 \\
\hline ProlNTA Quintal & 11.26 & 11.34 & 11.311 & 2.29 & 3.211 & 2.74 & 111.5 & 59.6 & 35.1 & 123 & 531 & 327 \\
\hline Klein Toledo & 2.44 & 2.79 & 2.61 & 5.52 & 6.97 & 6.24 & 14.3 & 57.1 & 35.7 & 222 & 591 & 4116 \\
\hline ProINIA Elite & 2.58 & 2.25 & 2.41 & 6.48 & 33.7 & 211.1 & 32.7 & 54.9 & 43.8 & 386 & 997 & 691 \\
\hline Buck Pronfo & (1.).38 & 2.119 & 1.23 & 3.99 & 3.96 & 3.97 & 29.9 & (61).4 & 45.1 & $31) 6$ & 564 & 435 \\
\hline ProINTA Granar & 10.73 & 4.94 & 2.83 & 4.45 & 41.5 & 23.11 & 32.11 & 58.4 & 45.2 & 333 & 1171 & 523 \\
\hline Klein Granador & 11.44 & 1.117 & 10.75 & 1.26 & 8.69 & 4.97 & 17.6 & 73.7 & 45.6 & 165 & 737 & 451 \\
\hline Klein Don Enrique & 10.84 & 11.38 & 0.61 & 7.76 & 2.69 & 5.22 & 52.5 & 41.1 & 46.8 & 551 & 375 & 463 \\
\hline Buck Panadero & 1.46 & 2.118 & 1.77 & 3.62 & 9.59 & 6.611 & 34.2 & (11.1) & 47.6 & 343 & 658 & $5(1)$ \\
\hline Klein Brujo & 11.49 & (1.51) & (1. 49 & 4.62 & 311.9 & 17.8 & 28.9 & 68.3 & 48.6 & 3119 & 11145 & 677 \\
\hline Klein Pegaso & 11.119 & (1.2(1) & 11.14 & (1. 38 & 5.24 & 2.81 & 57.2 & 411.9 & 49.11 & 465 & 412 & 438 \\
\hline ProINTA B. Redomion & 11.15 & 2.119 & 1.12 & 1.91 & 24.1 & 13.11 & 26.9 & 71.2 & 49.11 & 247 & 971 & 6119 \\
\hline Buck Poncho & 11.13 & 1.45 & 10.79 & 3.51 & 22.7 & 13.1 & 28.1 & 73.11 & 511.6 & 282 & 958 & 6211 \\
\hline Buck Charria & 1.12 & 1.79 & 1.45 & 7.711 & 211.4 & 14.11 & $31) .2$ & 72.5 & 51.3 & 373 & 921 & 647 \\
\hline Bonaerense Pericion & 11.28 & 1.47 & 11.87 & 1.23 & 411.4 & 211.8 & 28.8 & 74.7 & 51.7 & 252 & 1256 & 754 \\
\hline Couperaciein Calcpuín & 11.41 & 11.91 & 11.66 & 2.117 & 5.93 & 4.1111 & 511.11 & 54.7 & 52.3 & 437 & 539 & 488 \\
\hline IBuck Candil & 11.96 & 3.114 & 2.1111 & 2.119 & 43.8 & 22.9 & 32.5 & 72.8 & 52.6 & 301 & 13117 & 8114 \\
\hline Klein Orión & 11.87 & 1.72 & 1.29 & 5.33 & 19.5 & 12.4 & 37.9 & 68.8 & 53.3 & 395 & 877 & 636 \\
\hline IBuck Caltriel & (I.4) & 2.13 & 1.26 & 1.54 & 37.1 & 19.3 & 29.9 & 77.3 & 53.6 & 267 & 1229 & 748 \\
\hline Klein Colure & 11.53 & 2.56 & 1.54 & 2.42 & 18.7 & I11.6 & 36.7 & 711.7 & 53.7 & 337 & 885 & 611 \\
\hline Thomas Aconcagua & 11.46 & 11.92 & 11.69 & 3.15 & 26.5 & 14.8 & 34.1 & 74.2 & 54.1 & 326 & 11124 & 675 \\
\hline Thomas Chapelen & 11.31 & 2.22 & 1.26 & 1.114 & $3(1) .3$ & 15.7 & 51.2 & 611.9 & 56.1 & 428 & Y911 & 7114 \\
\hline IBuck Arrayaín & 11.39 & 1.25 & 11.82 & 1.61 & 25.9 & 13.8 & 34.8 & 77.9 & 56.3 & 3117 & 11148 & 678 \\
\hline ProINTA Pigiic & 11.47 & 2.33 & 1.411 & 1.91 & 33.5 & 17.7 & 311.9 & 84.7 & 57.8 & 281 & 1232 & 756 \\
\hline Buck Fogiin & 11.88 & 4.28 & 2.58 & 2.51 & 25.5 & 14.11 & 44.3 & 72.4 & 58.3 & 4112 & 11121 & 711 \\
\hline Bunaerense Pasico & 11.14 & 1.117 & 11.611 & 1.56 & 52.4 & 27.11 & 32.11 & 87.11 & 59.5 & 282 & 1543 & 913 \\
\hline ProINTA Puntal & (1).11) & 11.19 & 11.119 & 1.75 & 13.2 & 7.47 & 52.4 & 67.5 & 59.9 & 447 & 753 & (6I)I) \\
\hline ProINTA Cincu Cerros & 11.19 & 2.63 & 1.41 & 3.79 & 34.11 & 18.9 & 36.9 & 83.11 & (6).1) & 357 & 1228 & 792 \\
\hline I'roINTA B. Caucjuén & 11.29 & 6.11 & 3.211 & 2.32 & 23.5 & 12.9 & 32.8 & 87.5 & (1). 1 & 3112 & 1125 & 713 \\
\hline Buck Arriern & $(1 . .31)$ & 11.82 & 11.56 & 3.58 & 17.6 & 111.6 & 53.5 & 66.9 & $(, 1) .2$ & 487 & 824 & 655 \\
\hline Buck Chanibergu & 1.84 & 4.34 & 3.114 & 4.54 & 18.11 & 11.3 & 32.8 & $9(1.3$ & 61.6 & 3511 & 11146 & 698 \\
\hline Klein Centauro & (1.1)6 & 4.21 & 2.13 & 9.112 & 20.1 & 14.6 & 48.7 & 77.2 & 62.9 & 534 & 973 & 753 \\
\hline Thonas Tupungatu & 11.118 & 8.6(1) & 4.34 & 3.81 & 47.8 & 25.8 & 59.5 & 67.2 & 63.3 & 537 & 1372 & 954 \\
\hline Buck Ombú & 1.19 & 6.21 & 3.711 & 4.311 & 17.11 & 111.6 & 42.9 & 84.1 & 63.5 & 422 & 994 & 7118 \\
\hline I'roINTA Federal & 11.56 & 11.44 & 11.53 & 4.119 & 5.43 & 4.76 & 65.6 & (14.1) & 64.8 & 595 & 6113 & 549 \\
\hline Conperacioin Maipún & 11.27 & 4.511 & 2.38 & 1.83 & 47.2 & 24.5 & 35.9 & 94.11 & $65.1)$ & 318 & 1543 & 931 \\
\hline Buck Guarani & 1.911 & 2.112 & 1.96 & 3.49 & 15.9 & 9.69 & 41.7 & 88.5 & 65.1 & 4115 & 978 & 691 \\
\hline ProINTA Oasis & 11.211 & 5.58 & 2.89 & 4.611 & 38.9 & 21.7 & 56.8 & 83.1 & 711.11 & $531)$ & 1332 & 931 \\
\hline Comperacioin Nalouel & 0.118 & 1.115 & 10.56 & 4.27 & $4(1) .7$ & 22.5 & 54.6 & 86.1 & 711.3 & $51) 6$ & 1349 & 927 \\
\hline ProINTA Imperial & 1.112 & 2.43 & 1.72 & 4.111 & 29.9 & 17.11 & 55.9 & 84.8 & 711.3 & 521 & 1176 & 848 \\
\hline Conperación Malanıbo & 11.115 & 4.1111 & 2.112 & 13.2 & 43.1 & 28.1 & 63.3 & 78.9 & 71.1 & 718 & 1.353 & 11136 \\
\hline ProINTA Real & 1.116 & 1.112 & 1.114 & 9.54 & 35.3 & 22.4 & 62.6 & 84.2 & 73.4 & 662 & 1247 & 954 \\
\hline Klein Cacipue & 11.36 & 3.65 & 2.1111 & 5.85 & 511.1 & 28.11 & (61). 5 & 88.5 & 74.5 & 5811 & 15411 & $10(10)$ \\
\hline ProlNTA Super & 11.24 & 11.84 & 11.54 & 1.411 & 27.4 & 14.4 & 64.9 & 85.4 & 75.1 & 544 & 1129 & 8.36 \\
\hline ProlNTA Guazí & 0.42 & 1.911 & 1.16 & 7.44 & 53.5 & 311.5 & 61.6 & 88.9 & 75.2 & 615 & 1583 & 11194 \\
\hline Thonas Nevado & 11.24 & 5.411 & 2.82 & 2.31 & 47.6 & 25.11 & 78.11 & 93.1 & 85.6 & 66,3 & 1549 & 11110 \\
\hline Avg. & 11.611 & 2.28 & 1.44 & 3.63 & 24.5 & 14.1 & 411.2 & 69.11 & 54.6 & 384 & 962 & 673 \\
\hline LSD(1).115) † & 3.29 & 5.55 & & 5.13 & 9.65 & & 12.2 & 12.4 & & 172 & 266 & \\
\hline
\end{tabular}

if Cultivars are placed in order according to the average of both years at GS 83 .

$\leftarrow$ ISD test $(P<\| 1.115)$ for comparisons of pycnidial coverage percentage and AUDPC hetween cultivars at three adult growth stages ivithin 2 yr.

AUDI'C (Table 6). However, the $R^{2}$ values were only significant at GS 70 and for the AUDPC in 2000. In those two cases, the regression coefficients were positive and significant for days to heading, but statistically not significant for plant height. We also tested a large set of multiple nonlinear regression models, with different numbers of predictors and different powers of these predictors. However, only for GS 83 and for the AUDPC in 1998 we were able to iclentify models with slightly higher probabilities of the $R^{2}$ value than for the multiple linear models. These models had an $R^{2}=0.24(P=$ $0.014)$ for GS 83 and $R^{2}=0.21(P=0.026)$ for the AUDPC. . The models indicated that plant height and heading date were negatively associated with pycnidial coverage and that the multiplicative coefficient $\left(x_{1}, x_{2}\right)$ was positively associated (due to the negative effects of plant height and heading date).

\section{Greenhouse Experiments}

\section{Experiment 1}

There was a high correlation between necrosis and pycnidial coverage percentage, mainly attributed to the appropriate conditions (temperature and humidity) for the development of Septoria tritici blotch (Table 7).

Cultivars differed for both resistance components. Necrosis percentage fluctuated between 17.6 and $76.3 \%$ and pycnidial coverage between 1.5 .6 and $69.7 \%$ for all cultivars. The most resistant cultivars in the field also showed low disease values in this experiment. Klein 
Table 5. Days to heading and plant height of 50 Argentinean wheat cultivars in two field experiments.

\begin{tabular}{|c|c|c|c|c|c|c|}
\hline \multirow[b]{2}{*}{ Cultivars† } & \multicolumn{3}{|c|}{ Days to heading } & \multicolumn{3}{|c|}{ Plant height } \\
\hline & 1998 & $2(1010)$ & $\underset{1908-2(1) 10}{\text { Avg. }}$ & 1998 & 21100 & $\begin{array}{l}\text { Avg. } \\
1008-2(11111\end{array}$ \\
\hline & \multicolumn{3}{|c|}{$-\mathrm{d}$} & \multicolumn{3}{|c|}{$\longrightarrow \mathrm{cm}$} \\
\hline Cooperación Maipún & 106 & 以) & 1112 & 62 & 56 & 5) \\
\hline Klein Don Enrique & 97 & $9(1)$ & 13 & 67 & 54 & 6(1) \\
\hline Buck Chambergo & 96 & 92 & 94 & 65 & 56 & (6) \\
\hline Buck Ombú & 92 & 9) & 91 & 66 & 55 & (6) \\
\hline ProINTA Real & 96 & 94 & y5 & 61 & 5) & 611 \\
\hline Cooperación Malaumbo & 101 & $1(1) 1$ & 1111 & 63 & (1) & 61 \\
\hline Granero INTA & 91 & 91 & り1 & 64 & (1) & 62 \\
\hline ProlNTA Fedleral & 96 & 84) & 92 & 65 & 5) & 62 \\
\hline Buck Candil & 110 & 105 & 1107 & 6.3 & 61 & 62 \\
\hline Buck Guaraní & 94 & 91 & 92 & 67 & 611 & 63 \\
\hline ProINTA Oasis & 1112 & 96 & ) & 67 & (6) & 63 \\
\hline Klein Cobre & 93 & 8) & 11 & 66 & 62 & 64 \\
\hline Klein Estrella & $1(1) 4$ & $11(14$ & 1116 & 71 & 5) & 65 \\
\hline Cooperación Millán & y) & 94 & 96 & 66 & 65 & 65 \\
\hline Buck Pronto & 91 & 9) & 9) & 711 & 61 & 65 \\
\hline Cooperación Calquín & 96 & 9) & అ3 & 66 & 5) & 65 \\
\hline ProINTA Puntal & 111 & 95 & 1113 & 66 & 65 & 65 \\
\hline ProlNTA Elite & 15 & 93 & 94 & 68 & 62 & 65 \\
\hline ProINTA Granar & $\% 6$ & 93 & 94 & 68 & 62 & 65 \\
\hline Thoumas Tupungato & 103 & 1112 & 1112 & 68 & 65 & 66 \\
\hline Buck Arrayín & 106 & 1112 & $1(1) 4$ & 67 & 67 & 67 \\
\hline Buck Poncho & $1(1) 2$ & 10010 & $1(1) 1$ & 711 & 66 & 68 \\
\hline Buck Arriero & 1118 & $1(1) 3$ & 1115 & (6) & 67 & 68 \\
\hline Klein Brujo & 98 & 94 & 96 & 74 & 63 & 68 \\
\hline ProlNTA Super & 111 & 97 & 1114 & 74 & 63 & 68 \\
\hline ProlNTA Guazú & 101 & 102 & 101 & (1) & 68 & 68 \\
\hline Thommas Nevado & 1010 & 98 & wy & 73 & 64 & 68 \\
\hline Klein Orión & 93 & 9 & y1 & 74 & 65 & (6) \\
\hline Cooperación Naluuel & 1115 & 1112 & 1113 & 71 & 67 & (6) \\
\hline Thomas Aconcagıa & 1116 & 1113 & 1114 & 71 & (6) & 711 \\
\hline Buck Fogrón & 104 & 1111 & 1112 & 71 & (6) & 711 \\
\hline $\begin{array}{l}\text { ProlN'TA Bunaerense } \\
\text { Caucuuén }\end{array}$ & 1115 & I11! & $1(1) 3$ & 73 & 68 & 70 \\
\hline ProIN'TA Quintal & 94 & 91) & 92 & 75 & 67 & 71 \\
\hline Buck Panadero & $1(1) 3$ & $100)$ & 1111 & 71 & 71 & 71 \\
\hline ProINTA Imperial & 155 & 911 & 12 & 74 & 68 & 71 \\
\hline Bonaerense fiasuco & 1113 & 1113 & 1113 & 73 & 70 & 71 \\
\hline Klein Pegaso & 106 & 1111 & 1113 & 74 & 70 & 72 \\
\hline ProlNTA Pigiite & 105 & 1111 & 1113 & 77 & 68 & 72 \\
\hline ProlNTA Cinco Cerros & 107 & 1115 & 106 & 77 & 68 & 72 \\
\hline Klein Volcán & 101 & 94 & 97 & 81 & 65 & 73 \\
\hline Bunaerense Pericín & 1112 & 104 & $1(1) 3$ & 75 & 71 & 73 \\
\hline $\begin{array}{l}\text { ProlNTA Bunaerense } \\
\text { Redomón }\end{array}$ & $1(1)$ & 1115 & 1117 & 76 & 72 & 74 \\
\hline Thomas Chapelco & 111 & 1114 & 1117 & 78 & 71 & 74 \\
\hline Buck Charrúa & 111 & 1113 & 1117 & 75 & 75 & 75 \\
\hline Buck Catriel & 112 & 1116 & I(1) & 78 & 73 & 75 \\
\hline Klein Tuledo & 89 & 84) & 80 & 82 & 711 & 76 \\
\hline Klein Centauro & 1113 & 100 & 101 & 80 & 76 & 78 \\
\hline Klein Dragón & 97 & 92 & 94 & 84 & 74 & 79) \\
\hline Klein Granador & 97 & 1) & 94 & 92 & 73 & 82 \\
\hline Klein Caci(ue & 106 & 101 & 1113 & 87 & 82 & 84 \\
\hline Avg. & 101 & 97 & ソツ & 72 & 66 & 69) \\
\hline LSD $(1.115) \div$ & 2 & 2 & & 6 & 7 & \\
\hline
\end{tabular}

$\dagger$ Cultivars are placed in order according to the average of plant height. $\doteqdot$ LSD test $(P<(1.115)$ for comparisons of days to heading and plant height betweell cultivars within 2 yr.

Dragón, Klein Volcán, and Klein Estrella showed the best resistance levels (Table 7). Multiple linear regression analysis showed no association between heading date and plant height with pycnidial coverage percentage $\left(R^{2}=0.0047, P=0.89\right)$. None of the nonlinear regression models were significant either.

\section{Experiment 2}

Significant differences were found for both disease parameters between cultivars and isolates and for the cultivar $\times$ isolate interaction (Table 8 ). Percentages of necrosis and pycnidial coverage from the greenhouse experiment with several isolates are presented in Table 9. For necrosis percentage, Klein Dragón and Klein Volcán followed by ProINT A Quintal and 'Buck Poncho' showed the best levels of resistance for the average of the seven isolates. For Klein Dragón, necrosis percentage varied between 7.5 and $35.1 \%$ for all isolates and for Klein Volcán between 7.0 and $26.8 \%$. For pycnidial coverage Klein Dragón, ProINTA Quintal, and Klein Volcán showed the lowest values for the average of the isolates. Considering each particular isolate, Klein Dragón varied between 0.5 and $32.6 \%$; Klein Volcán between 0.9 and $23.7 \%$, and ProINTA Quintal between 0.2 and $28.4 \%$ (Table 9).

For the whole set of cultivars and isolates, the correlation between necrosis and pycnidial coverage was 0.86 $(n=112, P<0.001)$. Buck Panadero with isolates IPO 92064 and 92065 showed lower values for pycniclial coverage than expected based on the values for the percentage of necrosis. Moreover, some other combinations showed slightly higher pycnidial coverage values than expected based on necrosis percentage (Klein Estrella with isolate IPO 99015 and 'Buck Guaraní' with isolate Il’O 99016).

\section{DISCUSSION}

Pycnidial coverage percentages in seedlings and in adult plants were correlated in the field using the isolate IPO 99013, but the correlation was not high $(r=0.26$ in 1998 and $r=0.68$ in 2000). There were three cultivars with combined seedling and adult plant resistance, but others showed better levels of resistance either in the seedling or in the adult stage. That means that selection in both stages should be done in breeding programs to achieve acceptable levels of resistance throughout the entire growing period. Arama (1996) found similar results. Kema and Van Silfhout (1997) observed that in general adult plants were more susceptible than seedlings, although differences between isolates were found.

Pycnidial coverage was highly correlated with necrosis percentage in both field and greenhouse experiments. This is in agreement with previous findings for field experiments (Arama, 1996; Brown et al., 2001), although in some cultivar $\times$ isolate combinations, high percentages of necrosis with low pycnidial coverage have been found. In our research, there were also some cultivars that showed higher pycniclial coverage than necrosis due to the presence of pycnidia in green areas. In the greenhouse, sometimes the correlation between the two disease parameters was not high (Arama, 1996). In our greenhouse experiment, relative humidity was kept as high as possible during the period after inoculation by means of humidifiers. Measurement of pycnidial coverage is considered more accurate because senescence and other diseases do not interfere in the results. However, previous investigations indicate that especially in field conditions, necrosis percentage also can be a good predictor of resistance, and is easier to measure (Brown et al., 2001).

We found variation in genetic resistance-measured 
Table (1. Multiple linear regression for pycnidial coverage caused by Mycosphaerella graminicola as dependent variable and with days to heading and plant height as independent variables for $\mathbf{5 0}$ Argentincan wheat cultivars at seedling stage, boot stage (GS 49), milk development (GS 70), and early dough stage (GS 83), and for the area under disease progress curve (AUDPC) in two field experiments.

Equation parameters ( $P$ value $)$

\begin{tabular}{|c|c|c|c|c|}
\hline \multirow[b]{2}{*}{ Growth stage/A UDPC } & \\
\hline & Constant ( $P$ value) & Dalys to heading & Plant height & $R^{2}$ (P value) \\
\hline \multicolumn{5}{|l|}{1998} \\
\hline Seedling & $62.7(P=11.112)$ & $-11.116(P=10.82)$ & $-11.19(P=0.37)$ & $0.112(P=10.62)$ \\
\hline GS 44 & $24.8(P<10.01111)$ & $-10.19(P<10.10111)$ & $-11.113(P=11.37)$ & $0.33(P<0.0101)$ \\
\hline G.S 711 & $37.9(P<11.11(1)$ & $-10.18(P=11.114)$ & $-11.14(P=11.119)$ & $11.15(P=0.112)$ \\
\hline GS 83 & $35.3(P=11.17)$ & $10.38(P=11.118)$ & $-11.48(P=11.112)$ & $0.14(P=10.113)$ \\
\hline AUDPC & $636(P=11.119)$ & $2.68(P=11.41)$ & $-7.311(P=11.112)$ & $11.11(P=11.116)$ \\
\hline \multicolumn{5}{|l|}{2111111} \\
\hline Secdling & $14.6(P=0.45)$ & $0.22(P=11.31)$ & $10.16(P=0.45)$ & $0.116(P=10.24)$ \\
\hline GS $49^{\circ}$ & $-11.55(P=11.95)$ & $11.15(P=11.17)$ & $-11.111(P=11.34)$ & $11.114(P=10.37)$ \\
\hline GS 711 & $-76.6(P=11.01114)$ & $1.24(P<11.11(1) 1)$ & $-11.25(P=11.35)$ & $11.31(P<11.0111)$ \\
\hline GS 83 & $4.114(P=10.91)$ & $11.73(P=11.119)$ & $-0.119(P=10.83)$ & $(1) .117(P=(1.211)$ \\
\hline AUDPC & $-211.31(P=11.11 .3)$ & $31.1(P=11.11114)$ & $11.114(P=1.1111)$ & $0.22(P=10.11(13)$ \\
\hline
\end{tabular}

Table 7. Necrosis and pycnidial coverage percentage (backtransformed values) caused by Mycosphaerella graminicola, days to heading, and plant height in 50 Argentinean wheat cultivars with isolate IPO 99013 at early dough stage (GS83) in the greenhouse (Experiment 1).

\begin{tabular}{|c|c|c|c|c|}
\hline Cullivarst & $\begin{array}{l}\text { Days to } \\
\text { heading }\end{array}$ & $\begin{array}{c}\text { Plant } \\
\text { height }\end{array}$ & Necrusis & $\begin{array}{l}\text { Pycniclial } \\
\text { coverage }\end{array}$ \\
\hline & l & $\mathrm{cm}$ & - $\%$ & $\%$ \\
\hline Klein Dragrin & 87.11 & 74.5 & 17.6 & 15.6 \\
\hline Klein Volcán & 89.5 & 72.11 & 25.1 & 201.5 \\
\hline Klein Estrella & 97.5 & (11).11 & 26.11 & 22.7 \\
\hline Granero INTA & 83.11 & 53.11 & 27.11 & 25.2 \\
\hline Klein Toledor & 811.5 & 711.5 & 311.2 & 26.4 \\
\hline ProINTA Quintal & 99.5 & 56.11 & 311.1 & 27.4 \\
\hline Klein Brujo & 90.5 & (63.1) & 32.2 & 311.01 \\
\hline Cooperación Millán & 88.5 & $56.1)$ & 32.4 & 311.1 \\
\hline Buck Poncho & $9(1.1)$ & 59.0 & 35.1 & 311.9 \\
\hline Buck Catriel & 11111 & 601.5 & 35.9 & 31.4 \\
\hline Klein Granador & 86.5 & 76.11 & 35.6 & 31.6 \\
\hline Buck Chambergo & 85.5 & 54.5 & 411.1 & 32.7 \\
\hline Buck Charria: & y9.11 & $(14.1)$ & 41.11 & 32.8 \\
\hline Buck Prontı & 83.11 & 59.5 & 35.6 & 32.8 \\
\hline Buck Panacleru & 91.0 & 59.5 & 35.11 & 32.9 \\
\hline ProlNTA Granar & 95.11 & 65.5 & 35.11 & 33.1 \\
\hline Bonaerense Pericion & 9(1.1) & $66.1)$ & $4(1) .2$ & 33.4 \\
\hline Buck Canclil & 98.5 & 51.5 & $4(1.1$ & 34.3 \\
\hline Buck Arriero & 95.5 & (11).11 & 44.7 & 34.4 \\
\hline ProlnTa Federal & $x(1.11$ & 511.11 & 411.1 & 35.2 \\
\hline ProlNTA Elite & 911.5 & 57.5 & 411.1 & 35.6 \\
\hline P'rolNTA Bonaerense Canupén & 93.11 & 62.11 & 45.6 & 35.7 \\
\hline ProINTA Bunaerense Redomín & 97.11 & 65.5 & 45.6 & 36.6 \\
\hline Klein Collre & 84.5 & 54.5 & 45.8 & 37.7 \\
\hline PruINTA Puntal & 93.11 & 68.11 & 46.6 & 39.5 \\
\hline ProlnTa Cincon Cerros & 85.11 & 58.11 & 511.1 & 411.3 \\
\hline Buck Arrayán & 94.11 & 56.11 & 55.6 & 411.4 \\
\hline ProlNTA Pigiie & 84.5 & 63.5 & 45.6 & 411.9 \\
\hline Klein Don Enripue & 86.5 & 58.5 & 511.1 & 41.7 \\
\hline Thomas Aconcagua & 94.5 & $6(1) .11$ & 45.6 & 41.7 \\
\hline Bomaerense Pasuco & 92.11 & 64.11 & 511.2 & 41.8 \\
\hline Cooperación Calyuín & 84.5 & 56.5 & 511.1 & 42.7 \\
\hline Klein Pegaso & 94.11 & 65.5 & 511.3 & 42.7 \\
\hline Buck Fuguin & 92.11 & (12.1) & 55.7 & 42.9 \\
\hline Buck Guaraní & 84.5 & 58.5 & 52.5 & 42.9 \\
\hline Buck Omhú & 84.5 & 58.11 & 52.8 & 43.11 \\
\hline Klein Orión & 85.5 & 66.5 & 47.5 & 44.1 \\
\hline Klein Centaurn & 91.11 & 711.5 & 511.2 & 44.2 \\
\hline Cooperación Maipún & 94.5 & 54.11 & 56.3 & 511.5 \\
\hline Thoumas Chapelcio & 99.5 & 69.11 & 56.4 & 52.4 \\
\hline Conperacioin Nahuel & 94.11 & $61.1)$ & 611.1 & 52.9 \\
\hline ProINTA Imperial & 86.11 & 59.11 & $6(1) .2$ & 53.4 \\
\hline Klein Caciyue & 94.11 & 77.5 & 611.4 & 57.2 \\
\hline ProINTA O:ısis & 89.11 & 611. 5 & 68.4 & 58.9 \\
\hline Conperación Malambon & 89.11 & 53.5 & 711.11 & 611.6 \\
\hline ProINTA Guazú & 86.11 & 55.11 & 71.11 & 61.8 \\
\hline ProlnTA Super & ฯ\%.11 & 65.11 & 711.1 & 63.3 \\
\hline ProINTA Real & 84.11 & 65.5 & 72.5 & $(14.1)$ \\
\hline Thomas Nevado & $9(1.1)$ & 64.11 & 76.3 & 69.7 \\
\hline Avg. & $9(1) .4$ & 61.7 & 46.8 & 39.8 \\
\hline LSD $(11.05) \div$ & & & 14.7 & 11.98 \\
\hline
\end{tabular}

$\Varangle$ Cultivars are placed in order according (1) pycnidial coverage percentage. $\stackrel{+}{+}$ LSI ) test $(P=11.115)$ for comparison uf necrosis and pyenidlal coverage percentage between cultivars within 2 yr. as percentage of pycnidial coverage - within a wide spectrum of cultivars grown in Argentina in 1998 and the old cultivar Klein Toledo. Cultivars can be classified from moderately resistant to susceptible in the adult stage with the Argentinean isolate IPO 99013 based on three experimental environments (two assays in the field and one in the greenhouse). A few cultivars also can be considered resistant in the seedling stage.

A cultivar $\times$ experiment interaction was found in the field experiments. Higher AUDPC values were generally observed in 2000 than in 1998, but a few cultivars showed similar values in both years. Some of the cultivars were the most resistant cultivars (Klein Volcán, Klein Estrella, Klein Dragón, Cooperación Millán, and Granero INTA). This indicates that the AUDPC of the most resistant cultivars was less influenced by environmental conditions compared with the susceptible cultivars.

Klein Volcán and Klein Dragón showed good levels of resistance to seven isolates in the adult stage. These two cultivars also showed a high level of resistance to IPO 99013 in the seedling stage. The level of resistance in the seedling stage was higher than in the adult stage and probably indicates that a gene for gene interaction is expressed at the seedling stage. Our findings suggests that nonisolate specific horizontal resistance may be present in these cultivars in the adult stage, but additional research with more isolates should be done to verify the results. Specific interactions have been reported by several researchers in seedlings (Eyal et al., 1985; Perelló et al., 1991; Ahmed et al., 1995; Ballantyne and Thomson, 1995; Kema et al., 1996a, 1996b). In the adult stage, Kema and Van Silfhout (1997) and Brown et al. (2001) reported cultivar $\times$ isolate interactions.

Results showed that resistance to Septoria tritici blotch is not genetically associated with heading date or plant height within a wide spectrum of cultivars grown in Argentina. In the seedling stage this is supported by the multiple linear regression analysis of heading date and plant height on pycnidial coverage, which showed no relationship between the resistance and any of the morphophysiological traits for either of the two field experiments. All cultivars reached GS 12 at the same time; thus, they were inoculated and scored at the same date and for that reason under the same weather conditions. In that way, no influence of weather conditions could 
Table 8. Analysis of variance for necrosis and pycnidial coverage percentage (backtransformed values) caused by Mycosphaerella graminicola in 16 wheat cultivars with seven isolates (Experiment 2).

\begin{tabular}{|c|c|c|c|}
\hline \multirow[b]{2}{*}{ Source of variation } & \multirow[b]{2}{*}{ df } & \multicolumn{2}{|c|}{ Mean squares $(P>F)$} \\
\hline & & Necrosis percentuge & Pycnidial coverage \\
\hline & 15 & $1301(P<10 .(0) 1)$ & $935.8(P<11.1111)$ \\
\hline Isolates & 6 & $1213(P<0 .(101)$ & $2150(P<11.0111)$ \\
\hline Cultivars $\times$ Isolates & 川 & $251.4(P<10.11(11)$ & $193.1(P<(1 .(1) 1)$ \\
\hline Error & 111 & 24.11 & 36.8 \\
\hline
\end{tabular}

have affected the level of resistance and its association with the morphophysiological traits.

In the adult stage, the lack of genetic association is supported by the fact that associations between susceptibility and heading date in the field were positive or negative depending on how weather conditions predispose the development of the disease in late or early cultivars. Associations between plant height and resistance were also variable in the field. In addition, in 1999 , the same experiment was performed under controlled conditions and the flag leaf was inoculated at heading (Experiment 1). In that way, effects of plant height and heading date on the development of the disease due to environment or epidemiological aspects were minimized. Conditions after inoculations in this experiment were similar for all cultivars independently of the date they reached the flag leaf stage. There was no influence of any of the morphological traits on the expression of the disease under the controlled conditions in this trial. For that reason, it is assumed that associations (negative or positive) found in the field experiments can be attributed to variation in weather conditions and not to genetic linkages among those traits.
Weather was more favorable for the expression of the disease in early cultivars because precipitation was higher and radiation lower for early cultivars than late ones in 1998. This was especially true when considering a period of $1.5 \mathrm{~d}$ before the beginning of the adult stage evaluations, which started on $28 \mathrm{Sept}$. and on $15 \mathrm{Oct}$. 1998 for the earliest and latest cultivars, respectively. Precipitation was 53.4 and $18.8 \mathrm{~mm}$ and radiation 3.511 and $5127 \mathrm{~W} \mathrm{~m}^{-2} \mathrm{~d}^{-1}$ for the period of $1.5 \mathrm{~d}$ before evaluation for the earliest and the latest cultivars, respectively. Negative associations between pycnidial coverage and days to heading in 1998 can be attributed to these differences in weather variables.

In contrast, no negative associations were found between days to heading and the pycnidial coverage percentage in 2000. Some positive associations were found at GS 70 and for the AUDPC. Precipitation and temperatures were higher at the beginning of the infection for the latest cultivars. Adult stage evaluations started on 17 October and 2 November for the earliest and latest cultivars, respectively, in 2000. Considering a period of $15 \mathrm{~d}$ before those dates, mean temperatures were 14.2 and $16.8^{\circ} \mathrm{C}$, precipitation 57.5 and $101.1 \mathrm{~mm}$, and mean relative humidity 71.9 and $92.4 \%$ for early and late cultivars, causing the significant positive associations between pycnidial coverage and days to heading. Under greenhouse conditions, temperatures from 17 to $25^{\circ} \mathrm{C}$ are optimum for disease development (Hess and Shaner, 1987; Shaw, 1990; Wainshilbaum and Lipps, 1991; Magboul et al., 1992; Chungu et al., 2000). High humidity or precipitation and low radiation at time of infection also have been indicated as conditions conducive to the development of Mycosphaerella graminicola (Holmes

Table 9. Means of necrosis (N) and pycnidial coverage percentage (P) caused by Mycosphaerella gramicola of 16 Argentinean wheat cultivars with seven Argentinean isolates in the greenhouse (Experiment 2).

\begin{tabular}{|c|c|c|c|c|c|c|c|c|c|c|c|c|c|c|c|c|}
\hline \multirow[b]{3}{*}{ Cultivar } & \multicolumn{14}{|c|}{ Isolate } & & \\
\hline & \multicolumn{2}{|c|}{ 1)2(1)(14 } & \multicolumn{2}{|c|}{921165} & \multicolumn{2}{|c|}{931114} & \multicolumn{2}{|c|}{ 9บ113 } & \multicolumn{2}{|c|}{ 99114 } & \multicolumn{2}{|c|}{ מעו15 } & \multicolumn{2}{|c|}{ 94116 } & \multicolumn{2}{|c|}{ Avg.t } \\
\hline & $\mathbf{N}$ & $\mathbf{P}$ & $\mathbf{N}$ & P & $\mathbf{N}$ & $\mathbf{P}$ & $\mathbf{N}$ & P & $N$ & $\mathbf{P}$ & $\mathbf{N}$ & $\mathbf{P}$ & $\mathbf{N}$ & $\mathbf{P}$ & $N$ & $\mathbf{P}$ \\
\hline & & & & & & & & & & & & & & & & \\
\hline Klein Dragín & 11.1 & 4.1 & 7.7 & 1.11 & 7.5 & 7.1 & 17.6 & 15.6 & 35.1 & 32.6 & 8.75 & 0.5 & 8.7 & 4.11 & 13.8 & 9.3 \\
\hline ProlNTA Quintal & 31.3 & 3.8 & 11.3 & 11.2 & 52.7 & 15.4 & $31) .1$ & 27.4 & 311.8 & 28.4 & 111.7 & 5.8 & 7.2 & 1.) & 24.) & 11.8 \\
\hline Klein Volcán & 12.1 & 11.5 & 7.11 & (1.) & 26.8 & 22.11 & 25.1 & 211.5 & 24.1 & 23.7 & 111.2 & 6.8 & 22.2 & 11.2 & 18.2 & 13.8 \\
\hline Buck Arrieru & 18.11 & 16.8 & 33.3 & 13.3 & 21.8 & 3.9 & 44.7 & 34.4 & 34.5 & 311.4 & 14.6 & 8.115 & 311.8 & 14.2 & 28.2 & 17.3 \\
\hline Buck Charrúa & 51.3 & 201.2 & 45.7 & 28.6 & 22.6 & 14.8 & 41.11 & 32.8 & 33.11 & 32.4 & 110.3 & 5.8 & 33.2 & 16.3 & 33.1 & 21.5 \\
\hline Buck Guarani & 11.8 & 2.7 & 41.11 & $3(1.1)$ & 17.6 & 18.6 & 52.5 & 42.9 & $4 \% .9$ & 43.6 & 6.8 & 4.45 & 21.6 & 23.2 & 28.7 & 23.6 \\
\hline Buck Poncho & 15.2 & 12.2 & 14.1 & 13.7 & 25.8 & 22.6 & 35.1 & 311.9 & 34.7 & 29.1 & 17.6 & 13.3 & 41.11 & 55.7 & 26.2 & 25.4 \\
\hline ProINTA Oasis & 44.1 & 18.7 & 21.8 & 6.3 & 9.3 & 4.4 & 68.4 & 58.9 & 64.4 & 64.4 & 38.8 & 26.7 & 111.2 & 3.) & 36.7 & 26.2 \\
\hline Klein Estrell:a & 31.1 & 2(1).1) & 611.7 & 15.11 & 35.11 & 25.1 & $26.1)$ & 22.7 & 35.11 & 27.5 & 56.1 & $6(1) .11$ & 311.11 & 22.5 & 39.1 & 27.5 \\
\hline Buck Panadero & $3(1) .9$ & 4.2 & 511.6 & 13.7 & 21.6 & 18.1 & 35.11 & 32.9 & 88.9 & 711.4 & 27.7 & 26.7 & 57.6 & 34.7 & 44.6 & 28.7 \\
\hline Klein Orión & 45.6 & 25.11 & 24.0 & 17.2 & 16.8 & 5.4 & 47.5 & 44.1 & 86.6 & 67.1 & 45.11 & $3(1.1)$ & $35.1)$ & $3(1 . .1)$ & 43.1 & 31.3 \\
\hline ProlNTAReal & 43.4 & 27.1 & ソ.7 & 8.112 & 57.6 & 34.7 & 72.5 & 64.11 & 63.11 & 47.2 & 35.11 & 30.11 & 35.10 & 22.2 & 45.2 & 33.3 \\
\hline ProINTA Puntal & 37.5 & 25.11 & $5(1.0)$ & 25.11 & 68.5 & 50.11 & 46.6 & 39.5 & 42.5 & 32.5 & $5(1) .11$ & $4(1) .11$ & 37.5 & 32.5 & 47.5 & 34.9 \\
\hline Buck Oıbú & 83.7 & 61.6 & 28.3 & 12.2 & 36.7 & 11.4 & 52.8 & 43.11 & $8 \% .1$ & $7(1) .1)$ & 46.7 & 23.11 & 91.4 & $5 \% .4$ & 61.2 & 411.1 \\
\hline Thomas Tupungalo & 17.11 & 7.8 & 36.6 & 23.6 & 55.1 & $2(1.0$ & $6(1) .2$ & 53.4 & 67.6 & 60.6 & 51.6 & 32.4 & $8 \% .4$ & 83.5 & 53.4 & 41.0 \\
\hline ProlNTAGranar & 69.5 & 46.2 & 16.11 & 16.11 & 82.4 & 58.9 & 35.11 & 33.1 & 97.1 & 75.2 & 52.11 & 39.8 & 92.1 & 85.7 & 63.4 & 511.7 \\
\hline Avg. & 34.7 & 19.2 & $2 \times .6$ & 14.11 & 34.9 & 211.8 & 43.1 & 37.3 & 54.8 & 46.3 & $31) .1$ & 22.1 & 411.2 & 31.3 & 38.11 & 28.9 \\
\hline \multicolumn{17}{|c|}{ LSD(i.(1)5) necrosis percentuget⿳亠丷厂巾 } \\
\hline Cultivars (C) & 3.7 & & & & & & & & & & & & & & & \\
\hline Isolutes (I) & 2.4 & & & & & & & & & & & & & & & \\
\hline Interaction $(C \times I)$ & 9.7 & & & & & & & & & & & & & & & \\
\hline \multicolumn{17}{|l|}{ LSD pycnidlial coverage } \\
\hline Cultivars (C) & 4.5 & & & & & & & & & & & & & & & \\
\hline Isolates (I) & 3.11 & & & & & & & & & & & & & & & \\
\hline Interaction $(C \times I)$ & 12.11 & & & & & & & & & & & & & & & \\
\hline
\end{tabular}

$\uparrow$ Cultivars are placed in order according to the average of pycnidial coverage percentage.

+ LSD test $(P=11.15)$ for comparisuns of necrosis and pycnidlial coverage percentage letween cultivars, isolates, and for the interaction cultivars $\times$ isolates. 
and Colhoun, 1974; Hess and Shaner, 1987; Shaw and Royle, 1989).

The lack of genctic associations between resistance and heading date agrees with research by Arama et al. (1999). As they mentioned, when one tries to assess true resistance of a range of cultivars, disease severity should be measured not at the same moment, but at the same stage of development. If, in our experiments, disease development had been measured at the same day in the adult stage for all cultivars, early cultivars would have been at GS 70 when late ones were at GS 49. That was demonstrated by the overlapping of the last date of evaluation for GS 49 and the first for GS 70 (data not shown). This would have caused high and significant negative associations between earliness and resistance due to differences in leaf age and because of differences in the duration of the period leaves were exposed to the disease.

Negative associations between shortness and resistance were mainly present in 1998 when weather conclitions were less conducive to the development of the disease than in 2000. Unfavorable conditions and larger distances between leaves in tall cultivars could have reduced the rain-splash dispersal of pycnidiospores causing this negative association. Associations with plant height also could depend on the presence of the teleomorphic state and the importance of the ascospore release during the growth of the wheat crop. Air-borne dispersal of ascospores could reduce the effect of plant height in the expression of the disease. In Argentina, the presence of the teleomorphic state during the whole growing period has been reported (Cordo et al., 1990, 1999).

In Argentina, information about resistance levels of actual cultivars with different isolates is scarce. The results of this research showed specific interactions between cultivars and isolates, although some cultivars showed moderate levels of resistance toward several isolates. Even if these cultivars are susceptible to other isolates, higher levels of resistance could be achieved by intercrossing them. In this germplasm, no genetic associations between earliness, plant height, and resistance to Septoria tritici blotch are evident. The associations that were observed are likely caused by environmental and epidemiological factors.

\section{REFERENCES}

Alımed, H.U., C.C. Mundt, and S.M. Coakley. 1995. Host-pathogen relationship of geographically diverse isolates of Septoria tritici and wheal cultivars. Plant Pathol. 44:838-847.

Arama, P.F. 1996. Ellects of cultivar, isolate and environment on resistance of wheat to Septoria tritici blotch in Kenya. Ph.D. thesis. Wageningen Univ., the Netherlands.

Arama, P.F., J.E. Parlevlice, and C.H. van Sillhout. 1999. Heading date and resistance $u$ Septoria tritici blotch in wheat not genetically associated. Euphytica 106:63-68.

Ballantyne, B., and F. Thomson. 1995. Pathogenic variation in Australian isolates of Mycosphaerella graminicola. Austr. I. Agric. Res. 46:921-934.

Ballayar, B., A.L. Scharen, and W.E. Kronstad. 1990). Associations helween dwarling genes $\mathrm{Rht}_{1}$ and $\mathrm{Rht}_{2}$ and resistance to Septoria tritici blotch in winter wheal (Triticum aestivtum L. em Thell). Theor. Appl. Genct. 79:422-426.

Brown, J.K.M., G.H.J. Kema, H.R. Forrer, E.C.P. Verstappen, L.S.
Arraiano, P.A. Brading, E.M. Foster, P.M. Fried, and E. Jenny. 20()1. Resistance of wheal cultivars and breeding lines to septoria tritici blotch caused by isolates of Mycosphaerella graminicola in licld trials. Plant Pathol. 5():325-338.

Camacho Casas, M.A., W.E. Kronstad, and A.L. Scharen. 1995. Septoria tritici resistance and associations with agronomic traits in wheal cross. Cron Sci. 35:971-976.

Chungu, C., G. Gilbert, and F. Townley-Smith. 2(1)()). Septoria tritici blotch development as affected by temperature, duration of leal weeness, inoculum concentration, and host. Plant Dis. 85:430-4.35.

Cordo, C.A., A.E. Perclló, H.E. Alippi, and H.O. Arriaga. 1990. Presencia de Mycosphaerella graminicola (Fuckel) Schrocter, lclcomorlo de Septoria tritici Rob. ex Desm. en triges maduros de la Argentina. Rev. Fac. Agron. Plata 66/67:49-55.

Cordo, C.A., M.R. Simon, A.E. Perelló, and H.E. Alippi. 1999. Spore dispersal of leal blotch pathogens of wheat (Mycosphaerella graminicola and Septoria tritici). p. 98-101. In M. van Ginkel el al. (cd.) Septoria and Stagonospora diseases of cercals: A compilation of global rescarch. CIMMYT, Mexico.

Danon, T., and Z. Eyal. 199(). Inheritance of resistance to two Septoria tritici isolates in spring and winter wheat cultivars. Euphytica 47: 20)3-214.

Eyal, Z. 1981. Integrated control of Septoria discases of wheat. Plant Dis. 65:763-768.

Eyal, Z., A.L. Scharen, and J.M. Prescott. 1985. Global insights into virulence freyuencies of Mycospharella graminicola. Phytopathology 75:1456-1462.

Eyal, Z., A.L. Scharen, J.M. Prescoll, and M. van Ginkel. 1987. The Septoria discases ol wheat. Concepts and methods of disease management. CIMMYT, Mexico.

(jicco, J.O., J. Dubcovsky, and L.E. Aranha Camargo. 20)(1)4. Aggressiveness and physiology specialization of Septoria tritici isolates. Sci. Agric. 61:414-421.

Hess, D.E., and G. Shaner. 1987. Elfect ol moisture and temperature on development of Seproria tritici blotch in wheat. Phytopathol(ugy 77:215-219.

Holmes, S.J.I., and J. Colhoun. 1974. Inlection of wheat by Septoria nodortum and S. tritici in relation to plant age, air temperalure and relative humidity. Trans. Br. Mycol. Soc. 63:329-338.

Jlibene, M., and F. El Beuami. 1995. Inheritance of partial resistance to Seproria tritici in hexaploid wheal (Triticum aestivum L.). p. 117-125. In L. Gilchrist et al. (ed.) Proc. of a Workshop, Mexico, DF, CIMMYT, Mexico. 2()-24 Sept. 1993. CIMMYT, Mexico, DF.

Jlibene, M., J.P. Gustalson, and S. Rajaram. 1994. Inheritance of resistance (o Mycosphaerella graminicola in hexaploid wheal. Plant Brecd. 112:301-310.

Kema, G.H.J., J.H. Annonc, R.S. Sayoud, C.H. van Sillhout, and M. van Ginkel. 1996a. Genctic variation for virulence and resistance in the wheat-Mycosphaterella graminicola pathosystems: I. Interaclions between pathogen isolates and host cultivars. Phytopathology $86: 20()-212$.

Kema, G.H.J., R.S. Salyoud, J.H. Annonc, and C.H. van Sillhoul 1996h. Genctic variation lor virulence and resistance in the wheatMycosphaerella graminicola pathosystem: II. Analysis of interactions between pathogen isolates and host cultivars. Phytopathol(ogy 86:213-220).

Kema, G.H.J., and C.H. van Sillhout. 1997. Genctic variation for virulence and resistance in the wheat-Mycosphaerella graminicola pathosystem: III. Comparative secdling and adult plant experiments. Phytopathology 87:266-272.

King, J.E., R.J. Cook, and S.C. Melville. 1983. A review of septeria discalses of wheal and harlcy. Ann. Appl. Biol. 1(1)3:345-373.

Lee, S., and F.J. Gough. 1984. Inheritance of Septoria leal hlotch (S. (ritici) and Pyrenophora tan spot ( $P$. tritici repentis) resistance in Triticum aestivum cv. Carilen 12. Plant Dis. 68:848-851.

Maghoul, A.M., S. Gung, D.G. Gilchrist, and L.F. Jackson. 1992. Environmental inlluence on the inlection of wheat by Mycosphaerella graminicola. Phytopathology 82:141)7-1413.

Perclló, A.E., C.A. Cordo, H.O. Arriaga, and H.E. Alippi. 1991. Variation in virulence of Septoria tritici Rob. ex Desm. isolates in wheal. Agronomic 11:571-579.

Plant Pathologist's Pockethook. 1974. The Commonivealth Mycologicall Institule Kew, Survey. Lamport Gilhert Printer, Reading, UK

Rillo, A.O., and R.M. Caldivell. 1966. Inheritance of resistance to 
Septoria tritici in Triticum aestivum subsp. vulgare, Bulgaria 88 (Abstr.). Phytopathology 56:897.

Rosiclle, A.A., and W.J.R. Boyd. 1985. Genetics of host-pathogen interactions to the septoria species of wheat. p. 9-12. In A.L. Scharen (ed.) Septoria of cereals. USDA-ARS Publ. 12. USDA, Washington, DC.

Rosielle, A.A., and A.G.P. Brown. 1979. Inheritance, heritability and breeding hehavior of three sources of resistance to Septoria tritici in wheal. Euphytica 28:285-392.

SAS Institute. 1989. SAS/STAT user's guide. Version 6.0. SAS Inst., Cary, NC.

Shatier, G., and R.E. Finney. 1977. The ellect of nitrogen lertilization on the expression of slow-mildewing resistance in Knox wheal. Phytopathology 67:1051-1056.

Shaw, M.W. I9y(). Ellects of lemperature leal welness and cultivar on the latent period of Mycosphaerella graminicola on winter wheat. Plant Pathol. 39:255-268.

Shaw, M.W., and D.J. Royle. 1989. An epidemiologically based forecasting scheme for Septoria tritici. p. 107-109. In P.M. Fried (ed.) Proc. Int. Workshop Sept. Dis. Cereales, 3rd, Zurich, Switzerland 4-7 July 1989. Swiss Federal Station for Agronomy, Zurich, Switzcrland.

Simón, M.R., and C.A. Cordo. 1997. Inheritance of partiat resistance to Septoria tritici in wheat (Triticum aestivum L.): Limitation of pycnidia number and spore production. Agronomic 17:343-347.
Simón, M.R., and C.A. Cordo. 1998. Diallel analysis of the resistance components to Septoria tritici in Triticum aestivum. Plant Breed. 117:123-126.

Simón, M.R., A.J. Worland, C.A. Cordo, and P.C. Struik. 2001. Chromosomal location of resistance to Septoria tritici in seedlings of a synthetic hexaploid wheal, Triticum spelta and two cultivars of Triticuml aestivum. Euphytica 119:149-153.

Van Beuningen, L.T., and M.M. Kohli. 199(). Deviation Irom the regression of infection on heading and height as a measure of resistance to septoria tritici blotch in wheat. Plant Dis. 74:488-493.

Van Ginkel, M., and S. Rajaram. 1993. Breeding for durable resistance in wheat: An international perspective. p. 25y-272. In T.H. Jacobs and J.E. Parlevlice (ed.) Durability of disease resistance. Kluwer Academic Publ., Dordrecht, the Netherlands.

Van Ginkel, M., and A.L. Scharen. 1987. Generation mean analysis and herilabilities of resistance to Septoria tritici in durum wheat. Phycopathology 77:1629-1633.

Wainshilbaum, S.J., and P.E. Lipps. 1991 . Ellect ol temperature and growth stage of wheat on development of leal and glume blotch caused by Septoria tritici and S. nodortum. Plant Dis. 75:943-998.

Wilson, R.E. 1979. Resistance (o Septoria tritici in two wheal cultivars determined by independent, single dominant genes. Australats. Plant Pathol. 8:16-18.

Zadoks, J.C., T.T. Chang, and C.F. Konzak. 1974. A decimal code for the growth stages of cereals. Weed Res. 14:415-421. 